\title{
THE IMPACT OF HOLOCENE CLIMATE ON THE DEVELOPMENT OF PREHISTORIC SOCIETIES IN SOUTHERN SIBERIA
}

\author{
Marianna Kulkova \\ Department of Geology and Geoecology, Radiocarbon Lab, State Herzen Pedagogical University, St. Petersburg, Russia. \\ Corresponding author. Email: kulkova@mail.ru. \\ Sergey Krasnienko \\ Institute for the History of Material Culture Russian Academy of Science, St. Petersburg, Russia.
}

\begin{abstract}
Geochemical data of ${ }^{10} \mathrm{Be},{ }^{14} \mathrm{C}, \delta^{18} \mathrm{O}$ obtained from natural archives (tree rings, ice sheets, varves, corals) indicates that the climate during the Holocene was not stable. The cosmogenic isotope fluctuations are bound by the periodicity on solar activity and climatic changes. The sharpest and most abrupt climatic deteriorations are registered in the Early and Middle Holocene at 8200, 5800, 5400, 4300, and $2800 \mathrm{cal} \mathrm{BP.} \mathrm{These} \mathrm{events} \mathrm{are} \mathrm{characterized} \mathrm{by} \mathrm{cold} \mathrm{conditions.} \mathrm{The} \mathrm{impact}$ of climate on human communities in steppe depressions in southern Siberia (Nazarovo, Minusinsk, and Turano-Uyuk) was noticeable. The differences of local landscape-climatic conditions in these depressions were connected with global climatic changes to determine the processes of occupation, development, and migrations of ancient societies during the Neolithic, Bronze Age, and Iron Age. The chronology of archaeological cultures was also correlated with the local and global climatic changes during the Early and Middle Holocene in southern Siberia. Here, we generalize the literature data about Holocene climatic changes and archaeological cultures in the southern Siberia region.
\end{abstract}

\section{INTRODUCTION}

Climatic fluctuations influenced the development of prehistoric societies. The Holocene period had one of the most favorable climates in human history. Recent investigations, however, have shown that this period was characterized by global climatic fluctuations connected with solar activity (see van Geel et al. 1998, 1999; Dergachev et al. 2003; Dergachev and van Geel 2004). Strong fluctuations of solar activity are recorded via cosmogenic isotopes like ${ }^{14} \mathrm{C}$ and ${ }^{10} \mathrm{Be}$ from different natural archives. Dergachev and van Geel (2004) conducted a spectral analysis of the non-stationary behavior of high-precision radiocarbon data observed in tree rings (Stuiver and Becker 1993) over the past $8000 \mathrm{yr}$ and showed that cyclic climatic variations with a duration of about $2400 \mathrm{yr}$ and $1500 \mathrm{yr}$ are caused by changes in solar activity. The cosmic rays produce cosmogenic isotopes ${ }^{10} \mathrm{Be}$ and ${ }^{14} \mathrm{C}$ in the Earth's upper atmosphere by bombarding atomic nuclei. The isotopes accumulated in different natural archives, such as tree rings, ice cores, corals, and lacustrine deposits with cycles of $2400 \mathrm{yr}$, and a less precise cycle of $1500 \mathrm{yr}$.

Evidence of Holocene climate variability and solar forcing on the climate has been apparent from natural archives. Patterson et al. (2004) noted the coeval fluctuation in the production rates of the cosmogenic nuclides ${ }^{14} \mathrm{C}$ and ${ }^{10} \mathrm{Be}$, and annual to millennial timescale changes in globally distributed proxies of drift ice suggest that celestial forcing plays a dominant role at centennial- ( 200-500 yr) and millennial-scale (1000-1500 yr) Bond cycle frequencies. The latest research on sea surface temperature (SST) in the northwestern Pacific off central Japan during the Holocene has found evidence of a regular pacing at 1500-yr intervals seen throughout both the Holocene and the last glacial period. This assumed oscillation was a response to external forcing (Isono et al. 2009). Recent high-resolution analyses of lake sediment from SW Alaska showed evidence of cyclic variations in climate and ecosystems during the Holocene (Hu et al. 2003). These variations occurred with periodicities similar to those of solar activity and appear to be coherent with time series of the cosmogenic nuclides ${ }^{14} \mathrm{C}$ and ${ }^{10} \mathrm{Be}$ as well as North Atlantic drift ice. Roth and Reijmer (2005) argue for the 260-, 380-, and the 500-600 yr quasi-periodic signals, which are found to be of climatic origin, whereas the millennial-scale fluctuations remain enigmatic, although solar forcing mechanisms seem likely. According to Bard and Frank (2006), the solar fluctuations were involved in causing widespread but limited climatic changes, such as the Little Ice Age (AD 1500-1800). 
Although the casual relationship between solar activity and climate is still poorly understood at present because other factors in addition to solar activity influence the climatic records, the comparison of radionuclide and climate records provides increasing evidence for an important influence of solar activity changes on the climate during the Holocene (Mayewski et al. 2004). Magny (2004) supported the hypothesis suggested by Denton and Karlén (1973) that the residual ${ }^{14} \mathrm{C}$ record in tree rings may be an empirical indicator of Holocene paleoclimate. According to Dergachev (Dergachev and van Geel 2004; Dergachev et al. 2007), the increase of ${ }^{14} \mathrm{C}$ concentration in tree rings shows the cyclic variations and marks the episodes of solar activity decrease and the cold climatic events. These cold phases were locked in oxygen isotopic fluctuations from the Greenland ice cores and other climatic proxy records (Bush 2005). They are characterized as very cold short phases. Many of these changes are sufficiently fast from the point of view of human civilization (i.e. a few hundred years and less) and so may be considered "rapid" (Mayewski et al. 2004). According to numerous studies, the global episodes of falling temperature synchronous with a period of low solar activity after the Younger Dryas (12,700-11,500 cal BP) were recorded at $8200 \mathrm{cal}$ BP (Magny et al. 2003; Heiri et al. 2004; Kofler et al. 2005), at 5800 and 5300 cal BP (Magny and Haas 2004); 4100 cal BP (An et al. 2006; Chen et al. 2006); at 2800 cal BP (van Geel et al. 2004; van Geel and Beer 2007); and around $500 \mathrm{cal} \mathrm{BP}$. The calibrated ages of these brief cold periods coincide with ${ }^{14} \mathrm{C}$ cosmogenic isotope anomalies, which are characterized by "plateaus" on the calibrated curves.

Model experiments by Goosse et al. (2002) show that the fluctuations in solar activity have been responsible for the decrease of thermohaline convection in oceans and expansion of polar atmospheric flows in the both hemispheres. It was assumed by Mullins and Halfman (2001), Lamy et al. (2002), Magny et al. (2003), and Herzschuh (2006) that these processes weakened the African and Asian monsoons due to the temperature decrease and the thermal contrast between land and oceanic air masses. On the other hand, the thermal gradient shift between high and low latitudes was registered. Hence, latitudinal shifts in the position and strength of the Westerlies accounted for the humid conditions in high and low latitudes. Some regions in southern Siberia and central Asia are located in the zone of Westerlies' influence. The territories in southern Siberia and central Asia are inner areas with continental climatic conditions, and are divided by mountain ridges into several depressions. This region is characterized by strong climatic differences, especially concerning effective moisture. The Tibetan Plateau, northwestern and north-central China, Mongolia, and southern Siberia are situated in the triangle of the Indian Monsoon, the Southeast Asian Monsoon and the Westerlies (Figure 1) (see Yu et al. 2006). Therefore, reconstructing the climate during the Holocene in southern Siberia and central Asia is a difficult task. During sharp cold events, the monsoonal circulation became weaker, but the Westerlies were shifting to the north and some areas of southern Siberia were under humid conditions. Such geographical features in this territory influenced the settlement of people and their social and economic structures. The appearance and expansion of prehistoric people in the depressions differed depending on the local climatic and landscape conditions. This paper presents information about the chronology of ancient cultures and the climatic fluctuations in different regions of southern Siberia, considering the impact of global climatic events on the cultural processes and migrations of prehistoric people. ${ }^{14} \mathrm{C}$ analysis was used as the instrument for correlation of archaeological and environmental events.

\section{DESCRIPTIVE BACKGROUND AND METHODS}

Southern Siberia comprises the intermountain depressions within the Altai and Sayan mountain systems. A chain of isolated depressions belonging to the ancient steppe belt in the center of Asia extends from Siberian temperate forests in the north to the desert and semi-desert depressions of NW Mongolia. Prevailing dry conditions determine the poor organic deposition and low accumula- 


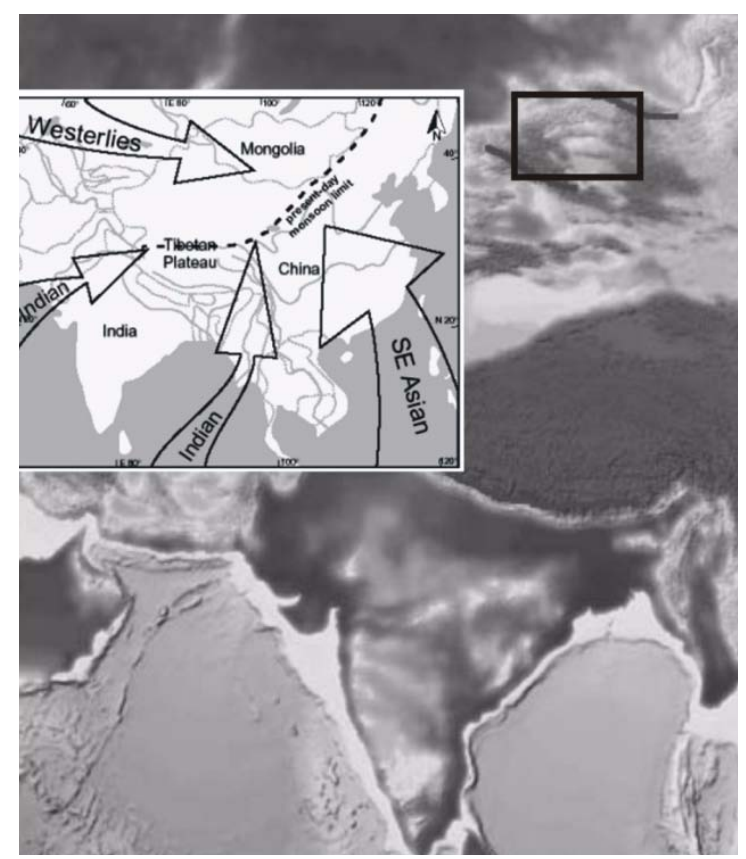

Figure 1 Region of southern Siberia and the distribution of air flows in Asia according to Yu et al. (2006).

tion rates in the region that prevent obtaining high-resolution records and their reliable chronology. Climatic changes during the Holocene and cultural processes were studied for the depressions Nazarovo, Minusinsk, and Turano-Uyuk (Figure 2). In this paper, all literature data on Holocene climatic changes and archaeological cultures in southern Siberia region are generalized.

The Nazarovo depression is located between the low-altitude mountain ridges Arga, Solgonskiy, and Batenevskiy. It borders a flat region of the Chulym River basin and the taiga of western Siberia. The depression is hilly with flat river valleys. The modern summer temperature is $16-18^{\circ} \mathrm{C}$, and the mean winter temperature is -16 to $-20^{\circ} \mathrm{C}$. These conditions characterize the temperate nature of the climate. In the depression, there are different types of landscapes: steppes, light forests, birch groves, floodplain, and bogs. To reconstruct the climatic conditions of the Holocene, deposits from Popovo Lake and paleosol from barrow 1 from the Beresh site near Sharipovo City were sampled and analyzed. Mineralogical-geochemical methods and ${ }^{14} \mathrm{C}$ analysis were used. The results were published recently (Kulkova and Krasnienko 2008, 2010). The mineralogical-geochemical methods for Holocene climatic reconstructions were published elsewhere (Chen et al. 1999; Koinig et al. 2003; Parker et al. 2006; Minyuk et al. 2007; Schwamborn et al. 2008). The most sensitive paleoclimatic markers determining the humid and cold climatic conditions of this region during the Holocene were used: TOC (total organic carbon) concentration, CIA (chemical index alteration of Nesbitt and Young; see Jahn et al. 2001), CaO/MgO ratio, and the mineralogical types of clay. The buried soils and their ages, determined by ${ }^{14} \mathrm{C}$ analysis, are another indicator of climatic changes.

The Minusinsk intermountain depression located north of the Sayan Mountains includes the Republic of Khakassia and the southern part of Krasnoyarsk Province (Figure 2). This is one of the largest depressions in southern Siberia. The climate is very continental with large seasonal temperature variations over $50{ }^{\circ} \mathrm{C}$ and a temperature inversion in winter. Forest-steppe exists at the outer areas 


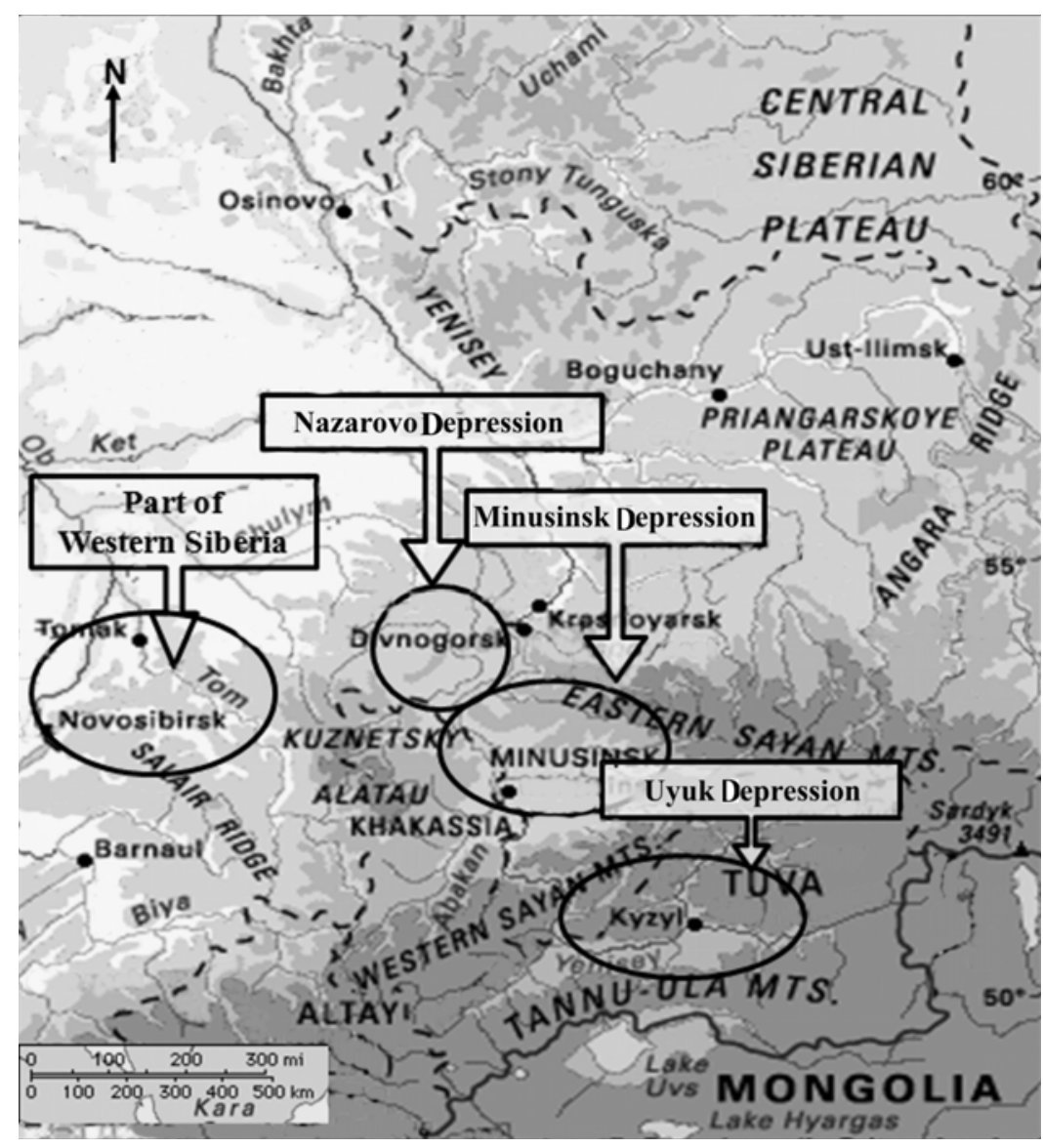

Figure 2 The main depressions of southern Siberia

of the depression from the foothills up to 700-1000 m elevations. The deposits from some freshwa-

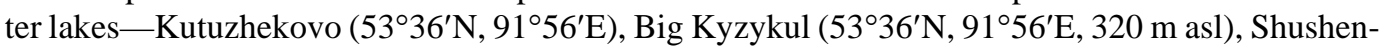
skoe $\left(53^{\circ} 19^{\prime} \mathrm{N}, 92^{\circ} 03^{\prime} \mathrm{E}, 300 \mathrm{~m}\right.$ asl) —and Tepsey loess cross-section $\left(53^{\circ} 59^{\prime} \mathrm{N}, 91^{\circ} 33^{\prime} \mathrm{E}\right)$ were sampled. For climatic reconstructions of the Minisinsk depression, pollen analysis, geochemical indicators of paleoclimate, and ${ }^{14} \mathrm{C}$ dating were applied (Kulkova 2004, 2005; Zaitseva et al. 2005; Dirksen et al. 2007a,b). The most significant features of cold and humid episodes were determined in pollen spectra by decreasing of frequency of xerophytic taxa like Artemisia and Chenopodiaceae, the sharp rise of Cyperaceae, the high frequency of tree pollen, and the characteristics of pine pollen species. Simultaneously, the deposits formed during these episodes are characterized by increasing TOC, and CIA, and C/N ratio parallels the considerable decrease of carbonates.

The southern part of the Turan-Uyuk depression is surrounded by the Sayan Mountains to the west and east and by the Uyuk mountain ridge to the south with an altitude of 1800-2300 m asl. The present climate is extremely continental with an annual temperature amplitude of $50^{\circ} \mathrm{C}$. Annual precipitation is $\sim 300 \mathrm{~mm}$. The Tuva intermountain depressions are characterized as open steppe.

For climatic reconstruction, the multiproxy indicators from deposits of freshwater White Lake-2 and buried eolian sediments from the Arzhan-2 barrow were used. Pollen analysis, geochemical indication of paleoclimate, and ${ }^{14} \mathrm{C}$ dating methods were applied. The results were published in a series of 
articles (see Kulkova 2004, 2005; Zaitseva et al. 2005; Dirksen et al. 2007a,b). The transition to cold and humid conditions is marked by the colonization of grasses and sedges on the lake shores, the replacement of halophytic communities by hygrophilous types, the increase of shrub birch pollen, the predominance of TOC in comparison with carbonate and sulfate complexes, and $\mathrm{C} / \mathrm{N}$ ratio increase. Chironomid data from some lakes of Tuva (Ilyashuk and Ilyashuk 2007) indicate that inferred climatic changes and the major climatic events (the last glacial-interglacial and the Late Glacial-Holocene transitions, B/A, Younger Dryas, 8.2 cal kyr BP, and Neoglaciation) marked in many records from both hemispheres imply that the events throughout the post-glacial climatic history of southwestern Tuva were generally non-local appearances.

The transition periods between warm and cold and dry and humid phases were determined on the basis of relative variations of climatic indicators (Zaitseva et al. 2005; Dirksen et al. 2007a,b). Figure 3 shows the chronology of climatic fluctuations for each depression. For comparison, the data on climatic changes in the southern area of western Siberia were used (Orlova and Zykina 2002; Orlova et al. 2007; Bezrukova et al. 2008). The periodization and chronology of ancient cultures of that territory have been studied thoroughly (Vadetskaya 1986; Bokovenko 1997; Krasnienko and Subbotin 1997; Erlich 1999; Gryaznov 1999; Alekseev et al. 2001, 2005; Chugunov et al. 2001, 2006, 2007; Görsdorf et al. 2001, 2004; Vasiliev 2001; Krasnienko 2002, 2003; Vdovina 2004; Zaitseva et al. 2004, 2005). Table 1 presents the chronological boundaries of archaeological cultures from different parts of southern Siberia based on archaeological and ${ }^{14} \mathrm{C}$ data. The conventional ${ }^{14} \mathrm{C}$ dates were calibrated using the OxCal v 3.10 program (Bronk Ramsey 1995, 2001) and the IntCal04 calibration curve (Reimer et al. 2004).

\section{RESULTS AND DISCUSSION}

The general scheme of environmental changes and development of archaeological cultures during the Early to Middle Holocene was constructed (Figure 3) on the basis of climatic reconstructions for southern Siberia. It is noteworthy that the major cold and humid events agree with global climatic events (Figure 3). Social adaptations varied in the degree of abruptness, magnitude, and duration of climate changes in different parts of region.

The Mesolithic and Neolithic cultures (8th-4th millennia BC) were not numerous in the intermountain depressions of southern Siberia. The Neolithic cultures developed in western Siberia and the Nazarovo depression at $\sim 8200$ cal BP ( 6250 cal BC). At that time, the Neolithic societies had just appeared in Uyuk and Minisinsk depressions (Lisitsin 1988). A layer with Neolithic artifacts from a cave situated near Kuilug-Khem River dates to 7670-7480 cal BP (5720-5530 cal BC). The climatic conditions at $\sim 8200$ cal BP were cold and humid; this event was a short-term period. After that, the climate became more dry and warm until $\sim 6300 \mathrm{cal}$ BP ( 4350 cal BC) when the climate changed again to a short and abrupt cold/humid event, which lasted from 300 to $600 \mathrm{yr}$ in different areas of southern Siberia. The next period was more dry and warm. Thus, the 2 short cold/humid abrupt climate changes during the Early Holocene are recorded in southern Siberia. Evidently, dry and warm climatic conditions were one of the reasons for the presence of a small number of the Mesolithic-Neolithic sites in the southern steppe zone. Occasional Neolithic artifacts were found only in the piedmonts. Ancient people presumably occupied the favorable ecological niches during the wettest episodes. At the end of Neolithic, people began to settle in the depressions of the Middle Yenisei region, evidenced by the rare archaeological finds and thin cultural layers in the steppe lakes of Khakassiya. The southern taiga and forest steppe zones of western Siberia were occupied by Neolithic communities and later by Aeneolithic and Early Bronze Age settlers. 


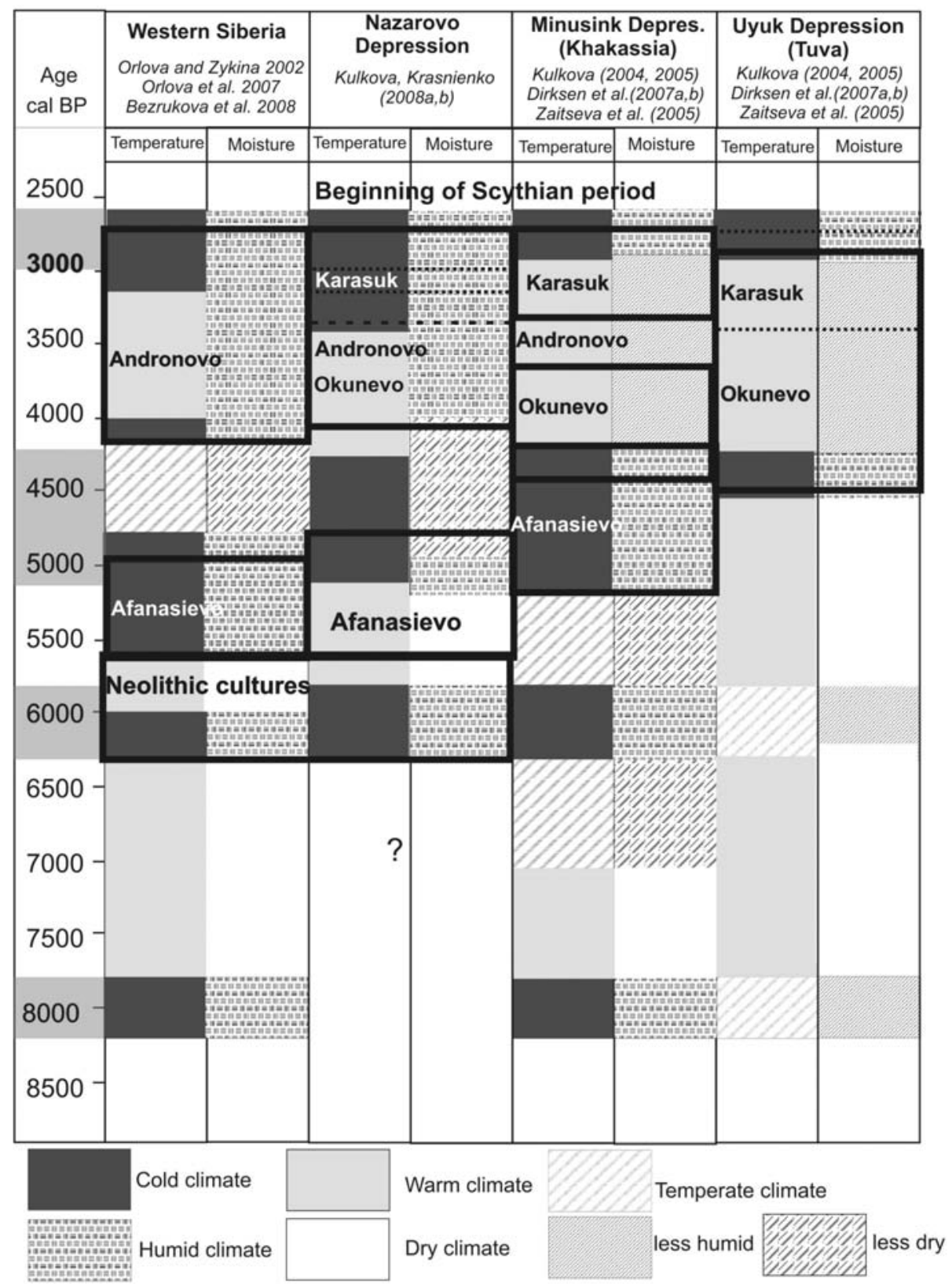

Figure 3 General scheme of climatic changes for each depression and development of archaeological cultures during the Early-Middle Holocene in southern Siberia and southern part of western Siberia.

The active occupation of southern Siberian steppe lasted from 5950 to $4950 \mathrm{cal}$ BP (4000-3000 cal BC). In the Nazarovo depression, cool and humid conditions were recorded at $\sim 5200$ cal BP ( $\sim 3250$ cal BC). The Afanasievo culture, which featured the first barrow (kurgan) complex of the region and the most eastern one in the system of Indo-European nomadic groups, appeared in this area at $~ 5550$ cal BP ( $3600 \mathrm{cal}$ BC). This was a stockbreeding culture that used metal (copper) (Vadetskaya 1986). 


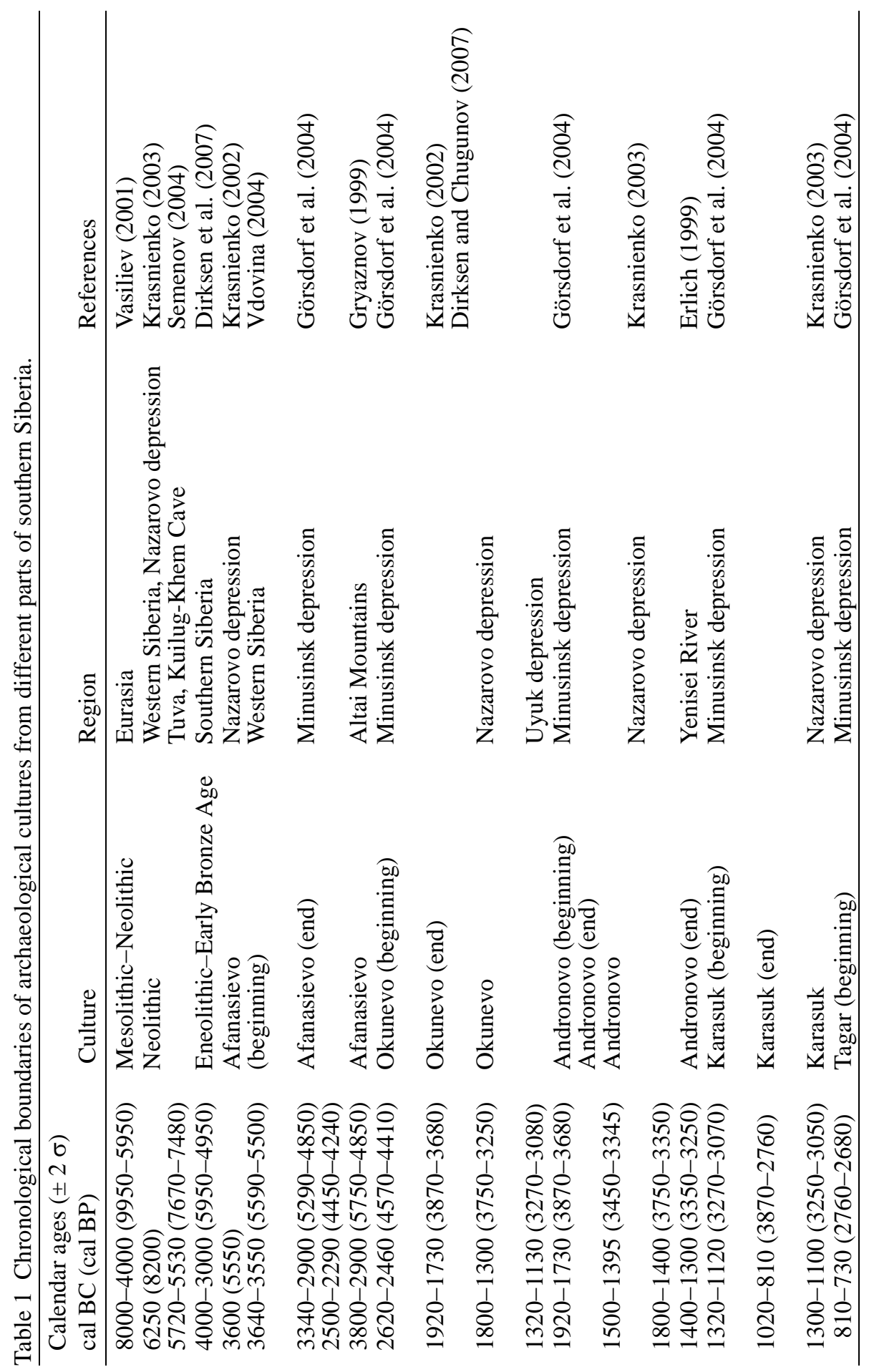


Among the Afanasievo sites in the Nazarovo depression, there are not only kurgans but settlements such as Oraki, Ashkil, and Glyadel VIII (Krasnienko 2002). In the Altai region, according to Gryaznov (1999), the Afanasievo sites date to 5750-4850 cal BP (3800-2900 cal BC). The earliest date of the wooden grave Elo-I from the Ongudai district in the Altai Mountains is 5590-5500 cal BP (3640-3550 cal BC). In the southern Minusinsk depression, the phase of cool and moist climate culminated at $\sim 5200$ cal BP ( 3250 cal BC). The bearers of Afanasivo culture expanded in this region during 5290-4850 cal BP (3340-2900 cal BC). At that time, the intermountain depressions of Tuva located in the southernmost part of the region were sparsely populated; sites of the Afanasievo culture were not founded. In the Tuva region, the climate still remained very warm and dry. Evidently, Nazarovo and Minusinsk depressions were occupied by people of Afanasievo culture due to an increase in humidity. The dry climatic conditions of Turan-Uyuk depression in that period hindered human existence. The dry steppes were not suitable for stockbreeding.

The Afanasievo culture was replaced by the Okunevo; both complexes coexisted for some time. The bearers of Okunevo culture occupied the steppe of Minusinsk depression from 4570-4410 cal BP (2620-2460 cal BC) to 3870-3690 cal BP (1920-1740 cal BC). The existence of this culture in the Turano-Uyuk depression is recorded until 3270-3080 cal BP (1320-1130 cal BC). Maximum humidity in this depression is recorded at 4500-4200 cal BP (2550-2250 cal BC). The climate of Minisinsk depression was humid and cold, while in the Nazarovo depression and in the southern part of western Siberia the conditions were less humid. In the Nazarovo depression, the amount of Okunevo sites is much smaller than south of this area. They were attributed to 3750-3250 cal BP (1800$1300 \mathrm{cal} \mathrm{BC}$ ). According to data from the Okunevo graves, its people have Mongoloid features and belong to another racial type compared to the Afanasievo population. The Okunevo community was probably formed on the basis of local Neolithic groups. The tribes of Okunevo culture existed in the depressions of southern Siberia where the climate around 4500-4200 cal BP (2550-2250 cal BC) was more humid than in neighboring regions. The freshwater lakes increased in size, and the diversity of fauna grew; thus, the surrounding landscapes were suitable for hunting and fishing.

The climatic conditions changed at $\sim 4000 \mathrm{cal}$ BP ( $\sim 2050 \mathrm{cal}$ BC); in western Siberia the temperature increased. Climate remained sufficiently humid but became warmer. Climatic conditions in the Minisinsk and Turano-Uyuk depressions were drier than in the Nazarovo depression. It is necessary to note that most of the sites belonging to Andronovo culture of the Middle Bronze Age and dated to 3750-3350 cal BP (1800-1400 cal BC) were excavated first in the Nazarovo depression. In Minusinsk depression, less Andronovo sites were found, and only in its northern part. The time span for this culture in the Minusinsk depression ranged from 3720-3560 cal BP (1770-1600 cal BC) to 3450-3350 cal BP (1500-1400 cal BC). Andronovo sites were not found in the Turano-Uyuk depression.

The majority of studies suggest that the Andronovo culture belongs to the Indo-Europeans. This population moved from the north to Nazarovo depression around the Kuznetsk Alatau Mountains. According to Koryakova and Epimakhov (2007), the Andronovo culture (or cultural family) is represented by a great variety of settlements and burial grounds, and it is composed of several cultural lines of evolution: Petrovka-Sintashta (2000-1600 cal BC), Alakul' and Fedorovo (1500-1300 cal BC), and Sargary-Alexeevka (1200-1000 cal BC). It is traditionally accepted that the economy of the Andronovo culture was based on animal husbandry supplemented by some agriculture, hunting, fishing, and gathering. Andronovo stockbreeding is similar to that of eastern Europe with regard to herd composition. By this time, metallurgy was advanced and concentrated in centers of western Asia (the Urals, Kazakhstan, western Siberia, and the Altai Mountains), and metal production was surprisingly uniform throughout entire region. In the Yenisei River valley, the final stage of this cul- 
ture dates to 3350-3250 cal BP (1400-1300 cal BC). The favorable humid climatic conditions very likely were responsible for the penetration of Andronovo tribes in the hard-hitting areas of southern Siberia. The Nazarovo depression was more suitable for their occupation, but the Minusinsk depression was settled only in the northern part. Both the southern part of the Minusinsk depression and the Turano-Uyuk depression are characterized by an arid climate at that time. The dry steppes were not suitable for farming, which has a high profile for Andronovo society. It is possible in this case that the choice of landscape played a vital part.

The Karasuk culture replaced the Okunevo culture in the southern part of southern Siberia and the Andronovo culture in the northern districts. In the Turano-Uyuk and Minusinsk depressions, the Karasuk culture appeared at the same time, around 3410-2740 cal BP (1460-790 cal BC). The climate in the depressions in this period was warm and moderately dry. The Karasuk was one of the most outstanding complexes of Late Bronze Age in southern Siberia and central Asia. Thousands of burial mounds and settlements were discovered in the steppe zone. In the Nazarovo depression, humid conditions continued during this period, but temperatures decreased. The first sites of the Karasuk-Irmen culture in this area are dated to 3250-3050 cal BP (1300-1100 cal BC). The diverse types of this culture developed from central Kazakhstan to Mongolia and northern China. The Karasuk people have both Mongoloid and Europeoid features. Nomadic cattle-breeding prevailed in their economy. The vast steppe areas and temperate climate attracted the nomadic tribes in the southern districts of southern Siberia. It is very likely that some of them came to this territory from southwestern regions.

A decrease in temperature is registered throughout the region at $\sim 2800 \mathrm{cal}$ BP ( 850 cal BC), and corresponds to an increase in humidity. The steppes of intermountain depressions turned into excellent pasture landscapes. This time period corresponds to the expansion of nomadic Scythian cultures. They began to occupy this territory during the 1st millennium BC. In the Minusinsk and Nazarovo depressions, the Tagar culture developed at 2750-2680 cal BP (810-730 cal BC). At the same time, the Turano-Uyuk depression was occupied by the tribes of Aldi-Bel' culture.

Viewing these processes in light of global climatic changes allows us to distinguish some short and rapid cold climatic events during the Early-Middle Holocene in southern Siberia. In contrast to Europe where during these cold episodes very dry conditions existed (see Perry and Hsu 2000; Brooks 2006), in the majority of southern Siberian depressions the moisture increased. This is especially distinct in the southern part of the area and probably was connected to the characteristics of air flows. The Westerlies significantly influenced the climate. As a result of these types of climatic changes, the auspicious ecological niches developed in the intermountain steppe zones, the landscapes of which were not always suitable for human occupation. There is strong correlation between climatic changes and intensity of existence of humans. Some Neolithic sites are attributed to the period of 8200-5800 cal BP, and they are located mainly in piedmonts. Around $5300 \mathrm{cal} \mathrm{BP,} \mathrm{this} \mathrm{ter-}$ ritory was occupied by tribes of the Early Bronze Age. Around 4100 cal BP, the development of Early Bronze Age cultures and the appearance and expansion of Middle Bronze Age cultures is recorded. It is necessary to note that humid conditions controlled the processes of occupation and migrations of prehistoric people. The wettest conditions in this area at $2800 \mathrm{cal}$ BP resulted in the development of land suitable for pastures throughout the steppe zone and in the resulting expansion of Scythian nomadic tribes.

\section{CONCLUSION}

The complexity of the southern Siberian terrain, the division into depressions by mountain ridges, influenced the climatic differences. During cold events, the humidity increased from the more open 
northern areas to the southern areas. The southern depressions stayed drier in comparison to the northern depressions during the Early-Middle Holocene. The reconstruction and chronology of these events with the help of ${ }^{14} \mathrm{C}$ dating allows us to establish the connection between climatic factors and the appearance, development, and migrations of prehistoric people in the studied region.

The prehistoric peoples reacted to climatic changes because their existence depended on landscapeclimatic factors. They adopted and occupied the most favorable land with respect to economic activities. The northern depressions with more humid conditions were occupied more intensively, and as a result they are characterized by more diversity of archaeological cultures.

The analysis of global environmental changes, with the help of a calendar timescale derived from ${ }^{14} \mathrm{C}$ data, allows the possibility of correlating the most significant climatic events with the local climatic variations and the estimation of their influence on the formation of different landscape zones. It can be assumed that the global climate changes were some of the important factors controlling the development of prehistoric people. This is important for understanding occupation processes, development, and migrations of ancient societies in different parts of southern Siberia and neighboring regions. More research is needed to uncover the details of this process.

\section{ACKNOWLEDGMENTS}

This study is supported by Program of RAS Presidium "The adaptation of people and cultures to environmental changes, social and man-caused transformation.” We are grateful to Y V Kuzmin and $\mathrm{M}$ McClure for editorial suggestions on the original manuscript.

\section{REFERENCES}

Alekseev AYu, Bokovenko NA, Boltrik Y, Chugunov KV, Cook G, Dergachev VA, Kovalyukh N, Possnert G, van der Plicht J, Scott EM, Sementsov AA, Skripkin V, Vasiliev S, Zaitseva GI. 2001. A chronology of the Scythian antiquities of Eurasia based on new archaeological and ${ }^{14} \mathrm{C}$ data. Radiocarbon 43(2B): 1085-107.

Alekseev AYu, Bokovenko NA, Vasiliev SS, Dergachev VA, Zaitseva GI, Kovalukh NN, Cook G, van der Plicht J, Possnert G, Sementsov AA, Scott EM, Chugunov KV. 2005. Evrasia v Skifsky Period (Radiouglerodnaya i Arkheologicheskaya Khronologiya) [Eurasia in Scythian Period (Radiocarbon and Archaeological Chronology)]. St.Petersburg: Teza Publishers. 290 p.

An C-B, Fenga Z-D, Barton L. 2006. Dry or humid? MidHolocene humidity changes in arid and semi-arid China. Quaternary Science Reviews 25(3-4):351-61.

Bard E, Frank M. 2006. Climate change and solar variability: What's new under the sun? Earth and Planetary Science Letters 248(1-2):1-14.

Bezrukova EV, Belov AV, Letunova PP, Abzaeva AA, Kulagina NV, Fisher EE, Orlova LA, Sheifer EV, Voronin VI. 2008. Peat biostratigraphy and Holocene climate in the northwestern mountain periphery of Lake Baikal. Russian Geology and Geophysics 49: 413-21.

Bokovenko NA. 1997. Noviy tip pogrebalnih komplexov karasukskoy kulturi. [The new type of barrow com- plexes of Karasuk culture]. In: Masson VM, editor. Novye Issledovaniya Arkheologov Rossii i SNG: Materiali Plenuma IIMK RAN 28-30 Aprelia $1997 \mathrm{~g}$. St. Petersburg: Peterburgkomstat Publishers. p 29-31.

Bronk Ramsey C. 1995. Radiocarbon calibration and analysis of stratigraphy: the OxCal program. Radiocarbon 37(2):425-30.

Bronk Ramsey C. 2001. Development of the radiocarbon calibration program. Radiocarbon 43(2A):355-63.

Brooks N. 2006. Cultural responses to aridity in the Middle Holocene and increased social complexity. Quaternary International 151(1):29-49.

Bush A. 2005. $\mathrm{CO}_{2} / \mathrm{H}_{2} \mathrm{O}$ and orbitally driven climate variability over Central Asia through the Holocene. Quaternary International 136:15-23.

Chen F-H, Cheng B, Zhao Y, Zhu Y, Madsen DB. 2006. Holocene environmental change inferred from a highresolution pollen record, Lake Zhuyeze, arid China. The Holocene 16(5):675-84.

Chen J, An Z, Head J. 1999. Variation of Rb/Sr ratios in the loess-paleosol sequences of central China during the last 130,000 years and their implications for monsoon paleoclimatology. Quaternary Research 51(3): 215-9.

Chugunov K, Nagler A, Parzinger H. 2001. The Golden Grave from Arzhan. Minerva 13(1):39-42.

Chugunov KV, Parzinger H, Nagler A. 2006. Der Goldschatz von Arzan. Fin Furstgrab der Skythenzeit in der sudsibirischen Steppe. Munich: Schirmer. 78 p. 
Chugunov K, Parzinger H, Nagler A. 2007. Der Furstenkurgan Arzan 2. In: Parzinger H, editor. Zeichen des Goldenen Greifen. Konigsgraber der Scythen. New York: Prestel Publishers. p 69-82.

Denton GH, Karlén W. 1973. Holocene climatic variations: their pattern and possible cause. Quaternary Research 3(2):155-205.

Dergachev VA, van Geel B. 2004. Large-scale periodicity of climate change during Holocene. In: Scott EM, Alekseev AY, Zaitseva GI, editors. Impact of the Environment on Human Migration in Eurasia. Dordrecht: Kluwer Academic. p 159-83.

Dergachev VA, van Geel B, Bokovenko NA, Dirksen VG, Kulkova MA, van der Plicht J, Zaitseva GI. 2003. Climatic changes during the Holocene in the Eurasian steppe of Southern Siberia (Minusinsk and Uyuk hollows) and the development of archaeological cultures. Geophysical Research Abstracts 5:02738.

Dergachev VA, Raspopov OM, Damblon F, Jungner H, Zaitseva GI. 2007. Natural climate variability during the Holocene. Radiocarbon 49(2):837-54.

Dirksen VG, Chugunov KV. 2007. Turano-Uyukskaya kotlovina Tuvi: izmeneniya prirodnykh uslovii i dinamika ee osvoeniya v drevnosti (opyt rekonstruktsii). [The Turanu-Uyuk depression of Tuva: changes of environmental conditions and the dynamic of occupation in prehistoric time (the reconstruction experience)]. In: Savinov DG, Dluzhnevskay GV, Lazarevskay NA, editors. Kulturno-Ekologicheskie Oblasti: Vzaimodeistvie, Traditsii i Kulturogenez. St. Petersburg: SPb Gosudarstvennyi Universitet Publishers. p 139-65.

Dirksen VG, van Geel B, Bokovenko NA, Chugunov KV, Sementsov AA, Zaitseva GI, Cook G, van der Plicht J, Scott M, Kulkova MA, Lebedeva LM, Burova ND. 2007a. Izmeneniya prirodnoy sredy $\mathrm{v}$ golotsene i dinamika arkheologicheskikh kultur v gornykh kotlovinakh Yuzhnoy Sibiri [The changes of environment in Holocene and the dynamic of archaeological cultures in mountainous depressions of Southern Siberia]. In: Zaitseva GI, Kulkova MA, editors. Radiouglerod v Arkheologicheskikh i Paleoekologicheskikh Iissledovaniyakh. St. Petersburg: Teza Publishers. p 340-64.

Dirksen VG, van Geel B, Kulkova MA, Zaitseva GI, Sementsov AA, Scott EM, Cook GT, van der Plicht J, Lebedeva LM, Bourova ND, Bokovenko NA. 2007b. Chronology of Holocene climate and vegetation changes and their connection to cultural dynamics in southern Siberia. Radiocarbon 49(2):1103-21.

Erlich VA. 1999. Voprosi periodizatsii brozovogo veka Zapadnoy Sibiri v 1960 - seredine 1970 godov v otechestvennoi literature [The question of Bronze Age periodization in Western Siberia in Russian literature of the 1960s - mid-1970s]. Vestnik Omskogo Universiteta. Vypusk 2. p 59-67.

Goosse H, Renssen H, Selten FM, Haarsma RJ, Opsteegh JD. 2002. Potential causes of abrupt climate events: a numerical study with a three-dimensional climate model. Geophysical Research Letters 29:1-4.
Görsdorf J, Parzinger H, Nagler A. 2001. New radiocarbon dates of the north Asian steppe zone and its consequences for the chronology. Radiocarbon 43(2B): 1115-20.

Görsdorf J, Parzinger H, Nagler A. 2004. ${ }^{14} \mathrm{C}$ dating of the Siberian steppe zone from Bronze Age to Scythian time. In: Scott EM, Alekseev AY, Zaitseva GI, editors. Impact of the Environment on Human Migration in Eurasia. Dordrecht: Kluwer Academic. p 83-9.

Gryaznov MP. 1999. Afanasievskaya Kultura na Enisee. [The Afanasievo Culture on the Yenisei River]. St. Petersburg: Dmitry Bulanin. 136 p.

Heiri O, Tinner W, Lotter AF. 2004. Evidence for cooler European summers during periods of changing meltwater flux to the North Atlantic. Proceedings of the National Academy of Sciences USA 101(43):15,2858.

Herzschuh U. 2006. Palaeo-moisture evolution in monsoonal Central Asia during the last 50,000 years. Quaternary Science Reviews 25(1-2):163-78.

Hu FS, Kaufman D, Yoneji S, Nelson D, Shemesh A, Huang Y, Tian J, Bond G, Clegg B, Brown T. 2003.Cyclic variation and solar forcing of Holocene climate in the Alaskan Subarctic. Science 301(5641):1890-93.

Ilyashuk BP, Ilyashuk EA. 2007.Chironomid record of Late Quaternary climatic and environmental changes from two sites in Central Asia (Tuva Republic, Russia) - local, regional or global causes? Quaternary Science Reviews 26(5-6):705-31.

Isono $\mathrm{D}$, Yamamoto $\mathrm{M}$, Irino $\mathrm{T}$, Oba $\mathrm{T}$, Murayama $\mathrm{M}$, Nakamura T, Kawahata H. 2009. The 1500-year climate oscillation in the mid-latitude North Pacific during the Holocene. Geology 37(7):591-94.

Jahn B-M, Gallet S, Han J. 2001. Geochemistry of the Xining, Xifeng and Jixian sections, Loess Plateau of China: eolian dust provenance and paleosol evolution during the last 140 ka. Chemical Geology 178(1-4): 71-94.

Kofler W, Krapf V, Oberhuber W, Bortenschlager S. 2005. Vegetation responses to the $8200 \mathrm{cal}$. BP cold event and to long-term climatic changes in the Eastern Alps: possible influence of solar activity and North Atlantic freshwater pulses. The Holocene 15(6):779-88.

Koinig KA, Shotyk W, Lotter AF, Ohlendorf C, Sturm M. 2003. 9000 years of geochemical evolution of lithogenic major and trace elements in the sediment of an alpine lake - the role of climate, vegetation, and landuse history. Journal of Paleolimnology 30(3):307-20.

Koryakova LN, Epimakhov AV. 2007. The Ural and Western Siberia in the Bronze and Iron Ages. Cambridge: Cambridge University Press. 383 p.

Krasnienko SV. 2002. Pamyatniki afanasievskoy kultury na yugo-zapade Krasnoyarskogo kraya. [The monuments of Afanasievo culture in south-western part of Krasnoyarsk Province]. In: Piotrovsky YY, editors. Stepi Evrasii v Drevnosti i Srednevekovie. Kniga 1. St. Petersburg: Gosudarstvenny Hermitage Publishers. p 171-5. 
Krasnienko SV. 2003. Raskopki Sibirskoy expeditsii Instituta Materialnoy Kulturi v Nazarovskoi kotlovine [The excavations of Siberian Expedition of the Institute for the History of Material Culture in Nazarovo Depression.] In: Sedov VV, editor. Arkheologicheskie Otkrytiya 2002 Goda. Moscow: Nauka Publishers. p 379-81.

Krasnienko SV, Subbotin AV. 1997. Arkheologicheskaya karta Sharipovskogo rayona (Krasnoyarsky Kray) [Archaeological map of Sharipovo District (Krasnoyarsk Province)]. Arkheologicheskie iziskaniya 48. St. Petersburg: LIMK RAN Publishers. 108 p.

Kulkova MA. 2004. Applications of Geochemistry to paleoenvironmental reconstruction in Southern Siberia. In: Scott EM, Alekseev AY, Zaitseva GI, editors. Impact of the Environment on Human Migration in Eurasia. Dordrecht: Kluwer Academic. p 255-74.

Kulkova MA. 2005. Geokhimicheskaya Indikatsiya Landshaftno-Klimaticheskikh Usloviy v Golotsene $v$ Regionakh Dvinsko-Lovatskogo Basseina i Yuzhnoi Sibiri [Geochemical indications of landscape-paleoclimatic conditions during the Holocene in regions of Dvina-Lovat' Basin and southern Siberia]. Synopsis of PhD thesis. St. Petersburg. p 32.

Kulkova MA, Krasnienko SB. 2008. The impact of Holocene climate on the development of prehistoric societies in the Southern Siberia. Abstracts of the 5th International "Rymposium "Radiocarbon and Archaeology." \#27.

Kulkova MA, Krasnienko SB. 2010. Okruzhayushaya sreda i drevnee naselenie Nazarovskoi kotlovini (Yuzhnaya Sibir) v period Golozena [Environment and ancient people of Nazarovo depression (Southern Siberia) during the Holocene]. In: Nesterov EM, editor. Geologiya, geoecologiya, evoluzionnaya geografiya 10. St. Petersburg: Herzen State Pedagogical University Publishers. p 183-8.

Lamy F, Ruhlemann C, Hebbeln D, Wefer G. 2002. Highand low-latitude climate control on the position of the southern Peru-Chile Current during the Holocene. $\mathrm{Pa}$ leoceanography 17:1-10.

Lisitsin NF. 1988. K voprosu o neolite Khakassii [About the question on the Neolithic of Khakassiya]. Kratkie Soobshcheniya Instituta Arkheologii Akademii Nauk SSSR 193:15-20.

Magny M. 2004. Holocene climate variability as reflected by mid-European lake-level fluctuations and its probable impact on prehistoric human settlements. Quaternary International 113(1):65-79.

Magny M, Haas JN. 2004. A major widespread climatic change around $5300 \mathrm{cal}$. yr. BP at the time of the Alpine Iceman. Journal of Quaternary Science 19(5): 423-30.

Magny M, Bégeot C, Guiot J, Peyron O. 2003. Contrasting patterns of hydrological changes in Europe in response to Holocene climate cooling phases. Quaternary Science Reviews 22(15-17):1589-96.
Mayewski PA, Rohling EE, Stager JC, Karlén W, Maasch KA, Meeker LD, Meyerson EA, Gasse F, van Kreveld S, Holmgren K, Lee-Thorp J, Rosqvist G, Rack F, Staubwasser M, Schneider RR, Steig EJ. 2004. Holocene climate variability. Quaternary Research 62: 243-55.

Minyuk PS, Brigham-Grette J, Melles MV, Borkhodoev Y, Glushkova OY. 2007. Inorganic geochemistry of El'gygytgyn Lake sediments (northeastern Russia) as an indicator of paleoclimatic change for the last 250 kyr. Journal of Paleolimnology 37:123-33.

Mullins HT, Halfman JD. 2001. High-resolution seismic reflection evidence for middle Holocene environmental change, Owasco Lake, New York. Quaternary Research 55(3):322-31.

Orlova LA, Zykina VS. 2002. Radiocarbon dating of buried Holocene soils in Siberia. Radiocarbon 44(1): 113-22.

Orlova LA, Talibov AG, Ponomarchuk VA. 2007. Raspredelenie radiouglerodnykh dat dlya arkheologicheskikh pamyatnikov vtoroi poloviny golotsena lesostepnoi zony Zapadnoi Sibiri i ikh korrelyatsiya s izmeneniyami klimata [The distribution of radiocarbon dates for the archaeological sites of the second half of the Holocene in Western Siberian forest steppe and its correlation with climatic changes]. In: Zaitseva GI, Kulkova MA, editors. Radiouglerod v Arkheologicheskikh i Paleoekologicheskikh Issledovaniyakh. St. Petersburg: Teza Publishers. p 334-9.

Parker AG, Goudie AS, Stokes S, White K, Hodson MJ, Manning M, Kennet D. 2006. A record of Holocene climate change from lake geochemical analyses in southeastern Arabia. Quaternary Research 66(3): 465-76.

Patterson RT, Prokoph A, Chang A. 2004. Late Holocene sedimentary response to solar and cosmic ray activity influenced climate variability in the NE Pacific. Sedimentary Geology 172(1-2):67-84.

Perry CA, Hsu KJ. 2000. Geophysical, archaeological, and historical evidence support a solar-output model for climate change. Proceedings of the National Academy of Sciences USA 97(23):12,433-8.

Reimer PJ, Baillie MGL, Bard E, Bayliss A, Beck JW, Bertrand CJH, Blackwell PG, Buck CE, Burr GS, Cutler KB, Damon PE, Edwards RL, Fairbanks RG, Friedrich M, Guilderson TP, Hogg AG, Hughen KA, Kromer B, McCormac G, Manning S, Bronk Ramsey C, Reimer RW, Remmele S, Southon JR, Stuiver M, Talamo S, Taylor FW, van der Plicht J, Weyhenmeyer CE. 2004. IntCal04 terrestrial radiocarbon age calibration, 0-26 cal kyr BP. Radiocarbon 46(3):1029-58.

Roth S, Reijmer JG. 2005. Holocene millennial to centennial carbonate cyclicity recorded in slope sediments of the Great Bahama Bank and its climatic implications. Sedimentology 52(1):161-81.

Schwamborn G, Fedorov G, Schirrmeister L, Meyer H, Hubberten H-W. 2008. Periglacial sediment variations 
controlled by late Quaternary climate and lake level change at Elgygytgyn Crater, Arctic Siberia. Boreas 37(1):55-65.

Semenov VA. 2004. K probleme neolitizatsii Minusinskoi kotlovini i Tuvi (verhneeniseyskaya neoliticheskaya kultura) [The problem of Neolithization of Minusinsk depression and Tuva (Upper Yenisei Neolithic culture)]. In: Zaitseva GI, Timifeev VI, editors. Problemy Khronologii i Etnokulturnykh Vzaimodeistvii $v$ Evrasii. St. Petersburg: Teza Publishers. p 70-87.

Stuiver M, Becker B. 1993. High precision decadal calibration of the radiocarbon time scale AD 1950-6000 BC. Radiocarbon 35(1):35-65.

van Geel B, Beer J. 2007. Solnechnaya aktivnost i ekspansiya skifskih kultur [Solar activity and the expansion of the Scythian cultures]. In: Zaitseva GI, Kulkova MA, editors. Radiouglerod v Arkheologicheskikh i Paleoekologicheskikh Issledovaniyakh. St. Petersburg: Teza Publishers. p 365-80.

van Geel B, van der Plicht J, Kilian MR, Klaver ER, Kouwenberg JHM, Renssen H, Reyneau-Farrera I, Waterbolk HT. 1998. The sharp rise of ${ }^{14} \mathrm{C}$ ca. $800 \mathrm{cal} \mathrm{BC}$ : possible causes, related climatic teleconnections and the impact on human environments. Radiocarbon 40(1):535-50.

van Geel B, Raspopov OM, Renssen H, van der Plicht J, Dergachev VA, Meijer HAJ. 1999. The role of solar forcing upon climate change. Quaternary Science Reviews 18(3):331-8.

van Geel B, Bokovenko NA, Burova ND, Chugunov KV, Dergachev VA, Dirksen VG, Kulkova M, Nagler A, Parzinger H, van der Plicht J, Vasiliev SS, Zaitseva GI. 2004. The sun climate change and the expansion of the Scythian culture after 850 BC. In: Scott EM, Alekseev AY, Zaitseva GI, editors. Impact of the Environment on Human Migration in Eurasia. Dordrecht: Kluwer Academic. p 151-8.

Vadetskaya EB. 1986. Arkheologicheskie Pamyatniki v Stepyakh Eniseya [Archaeological Monuments in the Steppes of Yenisei River]. Leningrad: Nauka Publishers. $179 \mathrm{p}$.

Vasiliev SA. 2001. Pozdnie komplexy mnogosloinoi stoyanki Uy II i problema razvitiya kamennogo veka v golozene na Verkhnem Enisee [The later complexes of the multilayer site Ui-II and the problem of the development of the Stone Age cultures in the Upper Yenisei River basin during the Holocene]. Arkheologicheskie Novosti 8:62-76.

Vdovina TA. 2004. Avariinye raskopki na mogilnike Nizhny Ayri-Tash [The rescue excavations of Nizhny Ayri-Tash butrial ground]. Drevnosti Altaya 12:13.

Yu ZC, Zhao Y, Zhao C, Ito E, Kodama KP, Chen FH. 2006. Complex responses of regional climate on the northeastern Tibetan Plateau to Holocene large-scale climate forcing. Geophysical Research Abstracts 8: 09741.

Zaitseva GI, van Geel B, Bokovenko NA, Chugunov KV, Dergachev VA, Dirksen VG, Kulkova MA, Nagler A, Parzinger G, van der Plicht J, Bourova ND, Lebedeva LM. 2004. Chronology and possible links between climatic and cultural change during the first millennium BC in southern Siberia and Central Asia. Radiocarbon 46(1):259-76.

Zaitseva GI, Chugunov KV, Bokovenko NA, Dergachev VA, Dirksen VG, van Geel B, Kulkova MA, Lebedeva LM, Sementsov AA, van der Plicht J, Scott EM, Vasiliev SS, Lokhov KI, Bourova N. 2005. Chronological study of archaeological sites and environmental change around 2600 BP in the Eurasian steppe belt. Geochronometria 24:97-107. 